Jürgen Riegel SAC, Stuła jako znak stużby , ad intra”, w: Szata liturgiczna, red. Adelajda Sielepin CHR, Jarosław Superson SAC, Kraków 2016, s. 17-42.

DOI: http://dx.doi.org/10.15633/9788374386029.03

Jürgen Riegel SAC

TheOLOGISCHE FAKULTÄT TRIER

\title{
Stuła jako znak służby ad intra
}

W latach I929-I94I pod katedrą na położonej na Jeziorze Bodeńskim wyspie Reichenau prowadzono intensywne wykopaliska, podczas których odsłonięto m.in. grób opata Berno (ok. 978-I048), pełniącego tę funkcję w klasztorze na wyspie za czasów cesarza Henryka II. Chyba najbardziej zadziwiającym znaleziskiem w grobie opata Berno były odkryte podczas wykopalisk szczątki jego odzieży, wśród których łatwo zidentyfikowano albę i stułęr.

Strój liturgiczny przetrwał więc Iooo lat i dzięki temu można było noszącego go człowieka zidentyfikować jako osobę duchowną. $Z$ tej perspektywy strój liturgiczny stanowi insygnium, czyli coś, co pozwala rozpoznać cechy człowieka $\left(\right.$ insignis $^{2}$ ). Takie spojrzenie wykluczałoby jednak pewne istotne aspekty stroju, nadmiernie akcentując tylko jeden $\mathrm{z}$ nich.

Stuła podlega przy tym własnym regułom. W przeciwieństwie do elementu antycznego stroju, któremu zawdzięcza swoją nazwę ${ }^{3}$, nie okrywa ona człowieka. Przyporządkowanie jej więc do insygniów byłoby bardziej słuszne. Powstaje wtedy jednak pytanie: Dla kogo pełni ona funkcję insygnium?

1 Por. A. Bayer, B. Jenisch, Die Grabgewänder des Abtes Berno von Reichenau († I048). Untersuchungen der Abegg-Stiftung Riggisberg, b.m.d.w., s. I79n.

2 Por. K. E. Georges, Ausführliches lateinisch-deutsches Handwörterbuch, Bd. 2, s. 3Ion.

3 Por. E. Pochmarski, Stola, b.m.d.w., s. 253n. 


\section{STULA: POMIĘDZY UBIOREM A INSYGNIUM. ZNAK ROZPOZNAWCZY NA GRANICY DOSTRZEGALNOŚCI}

Ubiór okrywa człowieka. Celowo lub nie, wyraża, kim jesteśmy lub jak chcielibyśmy być postrzegani. Wybieramy więc strój, który wiąże się z naszym idealnym obrazem siebie ${ }^{4}$. Ze wszystkich środków umożliwiających przekazywanie obrazu własnej osoby żaden nie jest nam - dosłownie - bliższy niż ubranie. Uchodzi ono za naszą „drugą skórę"s. Jego znaczenie wynika także z faktu, że właśnie poprzez ubiór następuje symboliczna komunikacja.

Poza sporami dyskursywnymi i racjonalnymi dokonuje się wciąż także symboliczna komunikacja. Obiekty i rytuały, jak np. ubiór lub sposób traktowania ubioru, symbolizują przesłanie dotyczące społecznych wyobrażeń wartości. Związane są one z określoną konstelacją historyczną i kulturalną. Takie przesłanie jest uchwytne bezpośrednio i zmysłowo, dlatego jego oddziaływanie na człowieka jest szczególnie silne ${ }^{6}$.

Komunikacja odbywająca się poprzez przedmioty, np. poprzez ubiór, zawdzięcza swoją intensywność bezpośredniemu oddziaływaniu, bez szukania okrężnej drogi przez świat słów.

Ubiór używany w czasie mszy pełni dwie funkcje: jest odpowiedzią (przede wszystkim uczestników) na konieczność postrzegania siebie jako osoby uczestniczącej we mszy bez przybierania sztucznej pozy oraz (przede wszystkim u osób sprawujących urząd) wynika z konieczności właściwego wypełniania szczególnej roli podczas mszy świętej7. Konieczność wyboru odpowiedniego dla siebie stroju dotyczy także zwierzchnika. Jego strój musi mieć nie tylko właściwy rozmiar, ale też być odpowiednio dobrany do okoliczności, by uniknąć wrażenia braku spójności pomiędzy zewnętrzną formą i przesłaniem, pomiędzy tym, co się mówi i czyni, a sugerowaną

4 Por. C. M. Sommer, Der soziale Sinn der Mode. Kleidung und Mode aus sozialpsychologischer Sicht, w: Zweite Haut. Zur Kulturgeschichte der Kleidung, ed. A. Holenstein i in., Bern-Stuttgart-Wien 20I0, s. 243.

5 Por. C. M. Sommer, Der soziale Sinn der Mode..., dz. cyt., s. 242.

6 E. Hackspiel-Mikosch, Die Theorie der Uniform. Zur symbolischen Kommunikation einer männlichen Bekleidungsform am Beginn der Moderne, w: Zweite Haut. Zur Kulturgeschichte der Kleidung, ed. A. Holenstein i in., dz. cyt., s. 67.

7 Por. A. Gerhards, Geschichte - Gegenwart-Perspektiven, w: Casula. Katalog zu einer Ausstellung vom 3.6. - I6.8.1992 in der Kunst-Station Sankt Peter Köln, Köln I992, s. 90-9I. 
poprzez szatę posługę osoby. „Sprawowana w językach ojczystych liturgia, w zamierzeniu zrozumiała i weryfikowalna, wystawia na pośmiewisko osobę [sic!] noszącą szatę, lecz niespełniającą związanych z tym wymogów"8.

Wzajemne oddziaływanie ubioru i wykreowanego przez człowieka własnego wizerunku znalazło $\mathrm{w}$ języku niemieckim swe odzwierciedlenie w przysłowiu „Kleider machen Leute” (dosł.: „Ubiór czyni człowieka”)9. Język niemiecki akcentuje w ten sposób fakt, iż ubiór wpływa na postrzeganie osoby, która go nosi. Przeciwną wymowę ma przysłowie włoskie: „L'abito non fa il monaco" („Szata nie czyni jeszcze z człowieka mnicha”) ${ }^{\mathrm{r}}$. Jest to powiedzenie, którego autorstwo przypisuje się Giuseppe Manzoniemu ${ }^{\text {II }}$, i które odnosi się w swej istocie do przesłania z dekretu papieża Innocentego III: „quum monachum non faciat habitus, sed professio regularis" ${ }^{\text {"2. }}$. Nie jest to wypowiedź sensu stricto liturgiczna, ma jednak wyraźnie religijny charakter. Sam habit nie wystarczy, by zrobić człowieka takim, jaki ma być. Najpierw należy zadbać o to, by złożył śluby wieczyste, a potem wypełnił je swoim życiem.

To samo dotyczy stroju liturgicznego. Nie przedstawia on jedynie wyobrażenia celebransa o sobie samym. Szata wyraża samoświadomość osoby, która ją nosi i weń ubrana wykonuje czynności liturgiczne.

Wskazana zależność dotyczy także insygniów liturgicznych. Za insygnia liturgiczne uważa się te (należące do stroju ${ }^{13}$ ) znaki, które wyróżniają noszącą je osobę jako sprawującą posługę.

Jako liturgiczne insygnia definiuje się stułę, mitrę, pastorał i paliusz. Te przedmioty reprezentują osobę, która je nosi, i w tym względzie mają charakter

\footnotetext{
$8 \quad$ A. Gerhards, Geschichte-Gegenwart-Perspektiven, dz. cyt., s. 9In.

9 Por. Duden Redewendungen. Wörterbuch der deutschen Idiomatik, Mannheim-LeipzigWien-Zürich 2002, s. 4I6 (Duden Band, II).

10 Por. A. Arthaber, Dizionario comparato di proverbi e modi proverbiali italiani, latini, francesi, spagnoli, tedeschi, inglesi e greca antichi, Milano I986, s. 2.

11 Por. A. Manzoni, I promessi sposi, w: Tutte le Opere, ed. G. Orioli i in., Roma I965, s. 39I.

12 Por. Corpus Iuris Canonici, ed. A. Richter, E. Friedberg, Bd 2, Graz I955, s. 573.

13 Wśród insygniów wymienianych przez Rossiego tylko pastorał nie jest elementem stroju; por. P. Rossi, Vesti e insegne liturgiche. Storia, uso e simbolismo nel rito romano, Milano 2003, s. 22, n. 9. Do tej listy należałoby jednak dodać pierścień wręczany podczas konsekracji biskupa.
} 
insygniów. Wskazują one na urząd, służbę lub szczególną rolę w obrębie Kościoła ${ }^{14}$.

Jeśli więc zakwalifikujemy stułę do insygniów, to należy założyć, że odniesienie stroju liturgicznego do „humanum”'5 ma w jej przypadku mniejsze znaczenie niż jej funkcja reprezentacyjna, polegająca na tym, by osobę, która ją nosi, dostatecznie wyróżnić jako osobę konsekrowaną, sprawującą urząd kościelny.

Paradoksalnie jednak, przynajmniej podczas Eucharystii, stuła nie jest widoczna, ponieważ noszona jest przez kapłana pod ornatem ${ }^{16}$. Stuła diakona także jest niewidoczna, o ile nie zrezygnuje on $\mathrm{z}$ nałożenia dalmatyki ${ }^{17}$, co jest dopuszczalne np. przy mniej uroczystych okazjach. $Z$ jednej strony jest więc ona znakiem wykonywanej posługi, z drugiej zaś strony w wielu aspektach nie spełnia tego zadania, ponieważ jest niewidoczna. Argument Moniki Thonhauser, że odznaczenia także są często noszone pod okryciem wierzchnim $^{18}$, nie wydaje się po głębszym zastanowieniu przekonujący. Podążając za tym tokiem myślenia, należałoby zrezygnować z całego stroju liturgicznego kapłana, który w końcu w całości także stanowi „liturgiczny środek wyrazu”'19 pokazując, że Kościół gromadzi się na mszy jako Kościół niemający hierarchicznej struktury ${ }^{20}$. Kapłan w swojej szacie wycofuje się

14 „Definiamo insegne liturgiche la stola, la mitria, il pastorale, il palio. Sono oggetti rappresentativi di colui che li indossa, pertanto hanno il carattere di insegna, mostrando una carica, un ministero, un ruolo particolare all'interno della chiesa", zob. P. Rossi, Vesti e insegne liturgiche, dz. cyt., $2 \mathrm{In}$.

15 Por. A. Gerhards, Geschichte-Gegenwart-Perspektiven, dz. cyt., s. $90 n$.

${ }_{16}$ Theodor Schnitzler uznaje noszenie jej na ornacie jako przejaw mody; por. T. Schnitzler, Von Geschichte und Sinn der liturgischen Gewandung und Färbung, „Das Münster” 32 (1979), s. 97; o typowym sposobie noszenia zob.: Institutio Generalis Missalis Romani, w: Missale Romanum ex Decreto Sacrosancti Oecumenici Concilii Vaticani II instauratum auctoritate Pauli PP. VI promulgatum Ioannis Pauli PP. II cura recognitum. Editio typica tertia, Città del Vaticano 2002, s. 337.

17 Por. Institutio Generalis Missalis Romani, dz. cyt., s. 338.

18 Por. M. Thonhauser, Paramente: Textilien für ein Fest, „Heiliger Dienst” 64 (2010), S. 196 .

19 Por. M. Kunzler, ,,Kleider machen Liturgen”. Überlegungen zum liturgischen Gewand, „Heiliger Dienst” 64 (20I0), s. I80.

20 Por. Institutio Generalis Missalis Romani, dz. cyt., s. 335. 
jako jednostka i pozostawia przewodzenie Chrystusowi jako osobie, która działa prawdziwie.

Generalnie należy stwierdzić, że szata liturgiczna jest szatą zakrywającą, w której osoba (persona $=$ maska) kapłana schodzi na drugi plan i skrywa się, ponieważ właściwie działającą osobą jest Chrystus. Głos kapłana głoszący Słowo Boże rozbrzmiewa (per-sonare) przez zasłonę, szatę, która jednocześnie reprezentuje oddawaną Bogu cześćcri.

Poprzez strój liturgiczny można więc chyba osiągnąc to, czego nie mogą dokonać insygnia: naznaczyć kapłana jako osobę, która działa „w zastępstwie Chrystusa". Gdyby insygnium było widoczne na zewnątrz jako tylko znak służby kapłańskiej, mogłoby sprawiać wrażenie nadmiernego podkreślenia własnego autorytetu ${ }^{22}$. Gdy patrzeć z tej perspektywy, właściwe wydaje się noszenie stuły nie na zewnątrz szaty, chociaż jest to miejsce odpowiadające jej funkcji.

Stuła może spełniać to zadanie, jednak nie wobec wspólnoty, tylko wobec samego kapłana. Podczas Eucharystii stuła jest niewidoczna, a więc nieskuteczna jako insygnium, i nawet jeśli liturgiczna szata wierzchnia, jaką jest ornat, nie powinna być redukowana do funkcji insygnium ${ }^{23}$, to musi jednak koniecznie spełniać także i to zadanie. Tym mocniej jednak musi być zaakcentowana funkcja stuły ad intra, która zwłaszcza w chwili nakładania powinna uświadamiać kapłanowi lub diakonowi doniosłość jego liturgicznych czynności podczas mszy św.:

Osoby sprawujące urząd stają przed wspólnotą nie w swoim imieniu, lecz w imieniu i w osobie Chrystusa. Szata liturgiczna powinna być znakiem tej wewnętrznej postawy osoby sprawującej urząd; stanowi więc także napomnienie dla noszącej ją osoby, że powinna występować przed wspólnotą w postawie służebnej wobec Chrystusa ${ }^{24}$.

21 M. Thonhauser, Paramente: Textilien für ein Fest, dz, cyt., s. 195.

22 Por. A. Gerhards, Geschichte-Gegenwart-Perspektiven, dz. cyt., s. 93n.

23 Por. A. Gerhards, Textilien im Kontext von Kirchenraum und Liturgie. Bestandsaufnahme und Desiderate», „Das Münster” 54 (200I), s. 313; zob. także: J. Wagner, Die geschichtliche Entwicklung der liturgischen Gewandung. Welche Hinweise gibt sie uns für eine zeitgenössische Erneuerung?, „Das Münster” 32 (1979), s. 93.

24 R. Kaczynski, Über Sinn und Bedeutung liturgischer Gewänder, s. 96; podkreślenie: Riegel; zob. także A. Gerhards, Geschichte - Gegenwart-Perspektiven, dz. cyt., s. 92. 
Podczas nakładania stuły celebrans powinien sobie uświadomić, że rozpoczyna właśnie służbę dla Chrystusa, a dokładniej: że rozpoczyna posługę wobec całego Ciała Chrystusa, jego głowy i Jego członków (por. Kol I, I8). Liturgia sprawowana jest przez całe Ciało Chrystusa (,,et a mystico Iesu Christi Corpore, Capite nempe eiusque membris, integer cultus publicus exercetur" ${ }^{25}$ ), a więc w służbie całemu Ciału Chrystusa działa także kapłan (lub diakon), który wkłada stułę. Aby specjalnie podkreślić tak rozumiane znaczenie chwili nakładania stuły, należałoby być może ożywić w nowej formie tradycję modlitwy przy nakładaniu stroju. Chodzi tu o taką formę, która dostrzegając wady modlitw trydenckich (jak choćby nieadekwatną symbolikę, która w stule widziała „,szatę“, a ornat porównywała do ,jarzma"), w miarę możliwości by je korygowała ${ }^{26}$.

\section{O HISTORII STUEY}

\section{Etymologia i przedmiot}

Już etymologia wskazuje, że stuła zajmuje miejsce pomiędzy ubiorem i insy-

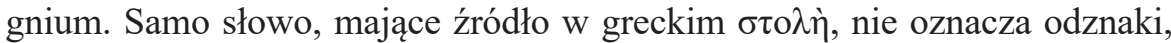
lecz ogólnie „,Szatę”27 albo „długą szatę”, która w starożytności noszona była przez kobiety zamężne i matki ${ }^{28}$. Jeszcze w IV wieku słowo „stuła” tak właśnie było rozumiane ${ }^{29}$.

Do stuły jako liturgicznego insygnium stosowano początkowo określenie „orarium”. W tym samym czasie, gdy to łacińskie pojęcie oznaczające ele-

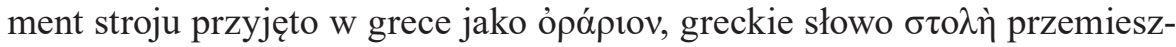

25 Constitutio de Sacra Liturgia Sacrosanctum Concilium, s. 7.

26 Por. M. Kunzler, Liturge sein. Entwurf einer Ars celebrandi, Paderborn 2007, s. 278-280.

27 Por. W. Pape, Handwörterbuch der griechischen Sprache, b.m.d.w., s. 946; zob. także: H. Leclercq, Étole, w: Dictionnaire d'Archéologie chrétienne et de Liturgie, Paris 1922, s. 674; J. Superson, Historia stuty, Kraków 20II, s. I2.

${ }_{28}$ Por. H. Leclercq, Étole, dz. cyt., s. 673; S. Piccolo Paci, Storia delle vesti liturgiche..., dz. cyt., s. 288; J. Braun, Die liturgische Gewandung im Occident und Orient, b.m.d.w., s. 565.

29 E. Pochmarski, Stola, w: Bildwörterbuch der Kleidung und Rüstung, ed. H. Kühnel, Stuttgart I992, s. 253n. 
czając się w odwrotnym kierunku, zostało przyjęte w łacinie jako „stola"3o. Podobnie jak przy pojęciu stuła, chodziło tu najpierw o przedmiot świecki: chustkę noszoną na szyi lub coś w rodzaju chusty do ocierania potu ${ }^{31}$. Słowo ópápıov jako pojęcie oznaczające element stroju liturgicznego znajdujemy na Wschodzie już w IV wieku, gdy Sobór w Laodycei zabraniał subdiakonom, lektorom i kantorom używania orarium przy wypełnianiu służby liturgicznej $^{32}$. Jak już zauważył Braun ${ }^{33}$, trudno byłoby uzasadnić tezę, że orarium odnosiło się do zwykłej chustki na szyję lub do ocierania potu. Można więc chyba założyć, że orarium już w IV wieku uchodziło, przynajmniej na wschodnim obszarze kulturowym, za szatę liturgiczną.

Pierwsza wzmianka o orarium w łacińskim obszarze kulturowym znajduje się w kanonie sformułowanym na I synodzie w Bradze w 56I roku. Stwierdzono w nim, że diakoni powinni nosić swoje orarium nie pod, lecz na tunice, by lepiej odróżniać się od subdiakonów ${ }^{34}$. Z tej wzmianki wynikają dwie rzeczy: po pierwsze, orarium wskazano tu jako wyróżniający element stroju, który w związku z tym powinien być widoczny na zewnątrz. Po drugie, w tym czasie orarium raczej nie mogło być już stosowane w celach praktycznych (jako chusta do ocierania potu), ponieważ byłoby to sprzeczne ze zwyczajem noszenia orarium pod tuniką. Diakoni nosiliby w takim przypadku orarium z czysto praktycznych względów na zewnątrz i nie trzeba by ich $\mathrm{z}$ tego powodu upominać35. Jeśli diakoni potrzebowali wcześniej orarium do służby liturgicznej, np. do udzielania komunii, to równie dobrze mogło ono spełniać obie funkcje: funkcję insygnium i funkcję praktycznego przedmiotu $^{36}$. Obie funkcje nie wykluczają się więc wzajemnie, jednak takie uregulowania, jak to zawarte w kanonie 9. Synodu w Bradze, sprawiają, że ojcowie synodalni wskazywali na stułę jako element wyróżniający osobę diakona, która ją zakłada, a nie jej praktyczne zastosowanie.

\footnotetext{
30 Por. J. Braun, Die liturgische Gewandung im Occident und Orient, dz. cyt., s. 565.

31 Por. A. Hollaardt, Orarium (orarius), w: Liturgisch Woordenboek 2, ed. L. Brinkhoff, Roermond 1968, kol. 2052; J. Braun, Die liturgische Gewandung im Occident und Orient, 563f; o innych teoriach na temat etymologii patrz: N.C. Schnabel OSB, Die liturgischen Gewänder und Insignien des Diakons, Presbyters und Bischofs in den Kirchen des byzantinischen Ritus, s. 3I-33.

32 Por. Concilium Laodicenum, ed. J. D. Mansi, s. 568.

33 Por. J. Braun, Die liturgische Gewandung im Occident und Orient, dz. cyt., s. 604.

34 Por. Concilios Visigoticos e Hispano-Romanos, ed. J. Vives, Barcelona-Madrid I963, s. 73.

35 Wbrew J. Braun, Die liturgische Gewandung im Occident und Orient, dz. cyt., s. 569.

36 Por. A. Papas, Liturgische Gewänder, dz. cyt., s. 745.
} 
W Galii już w VIII wieku zaczęto stosować określenie „stola”, w Rzymie natomiast aż do XIII wieku zachowała się nazwa „orarium”37. Potem jednak „orarium” zaczęło stopniowo wychodzić z użycia, wypierane przez określenie „stola” ${ }^{8}$. W dalszej części pracy nazwa „stola” używana będzie wszędzie tam, gdzie chodzi o ten element stroju w ujęciu ponadczasowym, tam natomiast, gdzie mowa jest tylko o wczesnym etapie rozwoju, stosowana będzie nazwa „orarium”.

\section{Warianty stosowania stuły w historii liturgii}

Wskazaliśmy już na możliwe znaczenia stuły wynikające z początkowego okresu jej używania. Ten punkt widzenia powinien zostać uzupełniony o perspektywę historyczną. Podstawę wszelkich pytań o znaczenie tego szczególnego elementu ubioru stanowi jego konkretne, praktyczne zastosowanie.

Orarium, o którym wspomina Synod w Bradze (56I), jest oznaką diakona. Jeśli noszenie orarium pod tuniką prowadziło do zamieszania, ponieważ nie można było odróżnić subdiakonów od diakonów ${ }^{39}$, nie musi to oznaczać, że zgodnie z kanonem diakoni nosili orarium na wierzchniej szacie. Należy raczej przyjąć, że w Hiszpanii w ogóle go nie używano, a tunika stanowiła odpowiednik rzymskiej alby ${ }^{40}$. Inaczej wyglądała sytuacja w obrządku praktykowanym w południowej Italii oraz rycie ambrozjańskim. Tam stuła diakonów noszona była na dalmatyce i spoczywała (podobnie jak w Hiszpanii) na lewym ramieniu ${ }^{4}$. W obu przypadkach stanowiła widoczną z zewnątrz oznakę.

Trudniej natomiast ocenić, jak to wyglądało w przypadku kapłanów. Zgodnie z kanonem 28. IV Synodu w Toledo (633) kapłan otrzymywał podczas święceń orarium i ornat ${ }^{42}$. Kanon nie mówi jednak nic o sposobie noszenia tych dwóch elementów ubioru. Sformułowana na III Synodzie w Bradze (675) opinia o stule biskupiej wskazuje jednak na to, że przez kapłanów noszona była (jak to jest praktykowane do dziś) pod ornatem, w obu przypadkach na

\footnotetext{
37 Por. A. Hollaardt, Stola, dz. cyt., s. 2594n.

38 Por. J. Braun, Die liturgische Gewandung im Occident und Orient, dz. cyt., s. 568.

39 Por. Concilios Visigoticos e Hispano-Romanos, ed. J. Vives, dz. cyt., s. 73.

40 Por. J. Braun, Tunic, dz. cyt., s. 87.

${ }^{41}$ Por. J. Braun, Die liturgische Gewandung im Occident und Orient, dz. cyt., s. 585n, 588.

42 Por. Concilios Visigoticos e Hispano-Romanos, ed. J. Vives, dz. cyt., s. $202 n$.
} 
obu ramionach i skrzyżowana na piersi. Jeśli przyjąć, że „sacerdos”, inaczej niż w tłumaczeniu w wydaniu Vives’a, można odnieść (także) do „kapłana"43, to pytanie staje się oczywiście bezprzedmiotowe.

Quum antica et ecclesiastica noverimus institutione praefixum, ut omnis sacerdos quum ordinatur orario utroque humero ambiatur, [...] qua ratione tempore sacrificii non adsumat quod se in sacramento accepisse non dubitat. [...] scilicet ut quum sacerdos ad sollemnia missarum accedit [...] non aliter accedat quam orario utroque humero circumseptus, sicut et tempore ordinationis suae dinoscitur consecratus, ita ut de uno eodemque orario cervicem pariter et utrumque humerum premens signum in suo pectore praeferat crucis ${ }^{44}$.

Jeśli więc biskup podczas święceń otrzymywał orarium, nonsensem byłaby - zgodnie z tezą Synodu - rezygnacja z niego przy wykonywaniu przez niego czynności sakramentalnych. Ten tok myślenia rodzi wrażenie, jakby stuła biskupia pomyślana była jako znak przypomnienia dla niego samego. To jednak bardziej wskazuje na noszenie jej pod szatą wierzchnią niż na niej. Należy przy tym jednak pamiętać, że od IX wieku ornat biskupi stał się bardziej obszerny i przez długi czas nie było jednolitej opinii na temat sposobu noszenia stuły (na czy pod dalmatyką? na czy pod tuniką? ${ }^{45}$ ).

Bardziej jednoznaczna sytuacja panowała w liturgii mozarabskiej, choć tu także trudne jest datowanie tekstów ważnego w tej kwestii dokumentu, czyli Liber Ordinum. Dokument pochodzi z XI wieku, ale zawarte w nim teksty, zwłaszcza te, które dotyczą celebrowania święceń kapłańskich, mogą sięgać nawet VI ${ }^{46}$ albo też VII wieku jako konsekwencja starań IV Synodu w Toledo związanych z dziełem liturgicznej reorganizacji przeprowadzonej

${ }_{43}$ Por. B. Kleinheyer, Studien zur nichtrömisch-westlichen Ordinationsliturgie. Folge 4: Zur Bewertung diverser Gewandüberreichungsriten im Licht ihrer Deuteworte, s. 223.

44 Concilios Visigoticos e Hispano-Romanos, ed. J. Vives, dz. cyt., s. 374n; w wydanych przez José Vives'a hiszpańskich tekstach synodalnych „sacerdos” thumaczony jest w tym miejscu jako „obispo” (biskup); także w sąsiednim galijskim kręgu kulturowym w VII wieku pojęcie „sacerdos” odnosiło się do biskupa, a nie kapłana w dzisiejszym rozumieniu; por. G. Predel, Vom Presbyter zum Sacerdos. Historische und theologische Aspekte der Entwicklung der Leitungsverantwortung und Sacerdotalisierung des Presbyterates im spätantiken Gallien, s. 197.

45 Por. J. Braun, Die liturgische Gewandung im Occident und Orient, s. 584.

46 Por. G. Predel, Vom Presbyter zum Sacerdos ..., dz. cyt., s. 209n.; P. F. Bradshaw, Ordination Rites of the Ancient Churches of East and West, s. I5n. 
za czasów biskupa Juliana z Toledo (680-690) ${ }^{47}$. Nie można więc wykluczyć bardzo starej tradycji tych jedenastowiecznych tekstów.

Przy święceniach kapłańskich Liber Ordinum przewiduje nałożenie orarium na szyję kandydata na kapłana, który (następnie) ubrany zostanie w ornat. „Quum venerit [h]is qui ordinandus est prebiter, appenditur ei orarium super cervicem et vestitur casulla ${ }^{48}$ ".

Noszenie stuły pod ornatem znajduje więc potwierdzenie w Liber Ordinum, chociaż nie ma tam żadnych informacji o motywach takiego sposobu jej noszenia.

Gdy więc w Hiszpanii prawdopodobnie już w VII wieku ornat stanowił szatę kapłańską i biskupią, w Rzymie jeszcze w VIII wieku według świadectwa Ordo XXXIV był strojem noszonym przez wszystkich kleryków, począwszy od akolitów (z wyjątkiem diakonów) ${ }^{49}$. Jeśli jednak już klerycy noszą tu „orarium”, to należy przyjąć, że chodzi w tym wypadku o „orarium” w pierwotnym sensie, czyli o „,chustę do twarzy”, nawet jeśli jest to prawdopodobnie jedyne źródło liturgiczne, które przez pojęcie „orarium” rozumie rzeczywiście coś w rodzaju chusty do twarzy ${ }^{50}$.

W tym samym Ordo ustalono, że podczas święceń diakon powinien zdjąć ornat i nałożyć dalmatykę (jako znak swoich święceń). Tu także konsekwentnie nie wspomina się o żadnym „orarium”, które miałoby być wręczane nowemu diakonowi. To dalmatyka jest jedynym znakiem jego służby ${ }^{51}$. Z tego wynikałoby więc, że w rzymskiej liturgii w okresie, kiedy nie oddziaływały na nią jeszcze wpływy frankijskie, stuła nie miała istotnego znaczenia.

Jedno ze źródeł z czasów karolińskich, a mianowicie kanony Synodu w Trebrze (895), zadekretowało nawet pozaliturgiczne używanie stuły przez każdego kapłana. „Ut a presbiteri non vadant, nisi stola vel orario induti. Et si in itinere presbiteri spoliantur vel vulnerantur aut occiduntur sine stola, simplici emendatione solvantur; si cum stola, tripliciter"52.

\footnotetext{
47 Por. Liber Ordinum Episcopal, ed. J. Janini, s. 44-47 (Studia Silensia, I5).

48 Liber Ordinum..., ed. J. Janini, dz. cyt., s. 95.

49 Por. M. Andrieu, ed., Ordo XXXIV, s. 603; A. Lameri, La Traditio Instrumentorum e delle insegne nei riti di ordinazione. Studio storico-liturgico (BEL.S 96), s. 63.

50 Por. M. Marinoni, Un'antica testimonianza iconografica sull'uso della stola diaconale in occidente, s. 92; M. Andrieu, Ordo XXXVI. I. Intruduction, s. I34n.

51 Por. Ordo XXXIV, ed. M. Andrieu, s. 604-6o6.

52 Capitularia Regum Francorum 2, ed. A. Boretius, V. Krause, s. 248 (Monumenta Germaniae Historica, Leg. 2, Cap. 2).
} 
W IX wieku żaden kapłan nie powinien więc w ogóle pokazywać się bez stuły na ulicy. Była ona oznaką jego godności, na co pośrednio wskazuje fakt, że kara za występek, którego ofiarą padł kapłan noszący stułę, była trzy razy wyższa niż kara za podobny występek popełniony wobec kapłana bez stuły. Nie można z całą pewnością stwierdzić, jak długo praktykowano takie pozaliturgiczne używanie stuły, tym bardziej że niektóre kanony zaprzeczają pozaliturgicznemu noszeniu stuły ${ }^{53}$.

Rzymskie Ordines XXXVI i XXXVIIa, które potwierdzają przekazywanie orarium diakonowi podczas święceń, mają także inne niż rzymskie pochodzenie ${ }^{54}$. W obu tych Ordines orarium przyszłego diakona występuje wyraźnie jako znak sakralny święceń, tym bardziej że już w noc poprzedzającą święcenia spoczywa ono na ołtarzu55. Wśród oryginalnych rzymskich dokumentów potwierdzających przekazanie wyświęconemu właśnie kapłanowi stuły w dzisiejszym rozumieniu Ordo XXXV (ok. 900) jest prawdopodobnie najstarszy ${ }^{56}$. Mowa w nim o zmianie ułożenia stuły57 po przekazaniu ornatu w trakcie związanej z tym ceremonii namaszczenia dłoni. Ornat jako szata i znak nie tylko kapłanów i biskupów funkcjonował jeszcze do roku I960 w formie planeta plicata: w dniach mających charakter pokutny diakoni nosili podczas posługi ornat opadający luźno z przodu. Zdejmowali ornat podczas czytania Ewangelii, by założyć go jak stułę, owijając wokół ciała $\mathrm{w}$ formie szarfy od lewego ramienia do prawego biodra ${ }^{58}$.

Interpretacja planeta plicata jako formy zbliżonej do stuły, jaką znajdujemy w Rationale Guillaume’a Duranda (XIII wiek), potwierdza w sposób pośredni, że także w rycie rzymskim stuła noszona była przez diakonów na lewym ramienius9. W odniesieniu do osoby określanej jako „sacerdos” -

53 Por. M. C. Miller, Clothing the Clergy. Virtue and Power in Medieval Europe, c. 80oI20O, S. $2 \mathrm{I}$.

54 Por. M. Marinoni, Un'antica testimonianza..., dz. cyt., s. 92.

55 Por. B. Kleinheyer, Studien zur nichtrömisch-westlichen Ordinationsliturgie, Folge 4: Zur Bewertung diverser Gewandüberreichungsriten im Licht ihrer Deuteworte, s. 222n.

56 Por. Ordo XXXV, ed. M. Andrieu, dz. cyt., s. 39.

57 Por. Ordo XXXV, I. Introduction, ed. M. Andrieu, dz. cyt., s. I4, n. 4.

58 Por. R. Berger, Liturgische Gewänder und Insignien, dz. cyt., s. 337.

59 Por. J. Braun, Die liturgische Gewandung im Occident und Orient, dz. cyt., s. 586; G. Durantis, Rationale Divinorum Officiorum I-IV, dz. cyt., s. I9I (Corpus Christianorum. Continuatio Medievalis, I40). 
czyli biskupa i (lub?) kapłana ${ }^{60}$ - Durand odwołuje się także do stwierdzeń synodu w Bradze, mając przy tym świadomość, że sposób noszenia polegający na skrzyżowaniu jej na piersiach nie jest powszechny. „Nam non ubique partes stole reducuntur ante pectus in modum crucis" ${ }^{\prime \prime}$.

Jeszcze w XII wieku jedno z kazań Iwo z Chartres potwierdza świadomie noszenie niekrzyżowanej stuły przez kapłanów i biskupów ${ }^{62}$. W swoim dziele Rationale Officiorum Durand musiał przyznać, że nie jest powszechnie stosowane to, co chętnie widziałby w swoim własnym pontyfikale jako stałą praktykę: skrzyżowanie stuły u kapłanów i odmienny sposób noszenia stuły przez kapłanów i biskupów. „Et quamquam inferiores presbiteri debeant orarium in modum crucis ante pectus reflectere, in episcopo tamen decet illius anterius deorsum dependere" $"$.

Po Soborze Trydenckim ta praktyka znalazła się w Missale Romanum z I570 roku.

Deinde ambabus manibus accipiens stolam, simili modo deosculatur, et imponit medium eius collo, ac transversando eam ante pectus in modum crucis, ducit partem a sinistro humero pendentem ad dextram, et partem a dextro humero pendentem, ad sinistram. Sicque utramque partem stolæ extremitatibus cinguli hinc inde ipsi cingulo coniungit. Si celebrans sit Episcopus, non ducit stolam ante pectus in modum crucis, sed sinit hinc inde utrasque extremitates pendere ${ }^{64}$.

Noszenie przez diakonów stuły pod dalmatyką poświadcza także ryt święceń zawarty w Pontifikale Romanum z 1595-1596 roku ${ }^{65}$ i reforma liturgii podjęta przez II Sobór Watykański niczego w tym względzie nie zmieniła. Zgodnie z Institutio Generalis odnowionego Missale Romanum

60 Jeszcze Hraban Maur († 856) stosuje określenie „sacerdos” do obu święceń kapłańskich; por. Hraban Maur, De Institutione Clericorum, I,5 (Fontes Christiani 6I,I).

61 G. Durantis, Rationale Divinorum Officiorum I-IV, I9I(Corpus Christianorum. Continuatio Medievalis, I40).

62 Por. Ivo von Chartres, Sermones, s. 524n (Patrologia Latina, I62).

63 M. Andrieu, ed., Le Pontifical Romain au moyen-âge, 3. Le Pontifical de Guillaume Durand, s. 634 (Studi e Testi, 88).

64 M. Sodi, A. M. Triacca, ed., Missale Romanum. Editio Princeps (I570), s. 9 (Monumenta Liturgica Concilii Tridentini, 2).

65 Por. M. Sodi, A. M. Triacca, ed., Pontificale Romanum. Editio Pronceps (I595-I596), s. 59 (Monumenta Liturgica Concilii Tridentini, I). 
kapłanów obowiązuje obecnie ten sam sposób noszenia stuły co biskupów, a więc bez krzyżowania, w prostym ułożeniu ${ }^{66}$, w obu przypadkach pod ornatem $^{67}$.

\section{Interpretacja z perspektywy historycznej}

\section{Konieczność redukcji}

Z perspektywy dokumentów posoborowej reformy liturgii kwestia interpretacji szat $i$ insygniów liturgicznych wydaje się dość prosta. Stanowią one ,znaki posługi” i noszone są przez tych, którzy w Kościele jako zróżnicowanym Ciele Chrystusa spełniają szczególne funkcje. Jednocześnie podkreślają odświętny charakter liturgicznej uroczystości ${ }^{68}$. Ponadto rozważania na temat symboliki specyficznych szat liturgicznych w kontekście posoborowym są same w sobie niestosowne.

Szaty liturgiczne są generalnie ,znakami i symbolami rzeczywistości nadprzyrodzonej” (,rerum supernarum signa et symbola”69). Osoby sprawujące urząd nie dysponują nimi dowolnie, tylko otrzymują je w chwili przyjmowania urzędu, by urzeczywistniać w tych szatach obecność Chrystusa i móc własną osobę coraz bardziej odsuwać na dalszy plan. W tym kontekście stuła jako insygnium jest znakiem urzędu, który przyznano diakonom i kapłanom ${ }^{70}$. Sam fakt przyznania im tego urzędu stanowi na tle posoborowej liturgii o znaczeniu tych insygniów.

Gdy jednak pytanie dotyczy ich znaczenia w perspektywie historycznej, ponownie stają się możliwe specyficzne interpretacje symboliczne.

Najłatwiej uniknąć nazbyt alegorycznych interpretacji, ograniczając się do symboliki, w której symbol i to, co on oznacza, są ze sobą możliwie ściśle wewnętrznie powiązane, a związek ten wynika z konwencji. „Pomiędzy symbolem i tym, co on oznacza, istnieje wzajemna relacja

\footnotetext{
66 Por. Institutio Generalis Missalis Romani, s. 340.

67 Por. Institutio Generalis Missalis Romani, s. 337.

68 Por. Institutio Generalis Missalis Romani, s. 335.

69 Por. Konstytucja o Świętej Liturgii Sacrosanctum Concilium, S. I22.

70 Por. R. Kaczynski, Über Sinn und Bedeutung liturgischer Gewänder, dz. cyt., s. 95; na temat stuły diakonów zob. też tamże, s. 94.
} 
podobieństwa, przynależności, bliskości itd., która umożliwia pewien rodzaj wymienialności podkreślającej wzajemne związki, które ją samą uzasadniają"7ı.

Tam więc, gdzie widoczne jest odniesienie oparte na podobieństwie, mamy do czynienia z uzasadnioną symboliką, i o taką jedynie nam tu chodzi. Przeciwieństwem tego rodzaju symboliki byłaby alegoryczność. Stuła byłaby w niej przybierającym dowolną postać wyrazem koncepcji intelektualnej lub duchowej, a nie analogicznym odpowiednikiem elementu posługi sprawowanej przez osobę, która ją nosi ${ }^{72}$.

\section{Stuła diakona}

IV Synod w Toledo (633) nie tylko ustalił, że diakoni nosić mają stułe na lewym ramieniu, lecz także dokonał interpretacji tego sposobu noszenia. Kanon 40. tego Synodu mówi, że nie godzi się, by diakoni nosili dwa oraria. Następnie w kanonie mowa jest o tym orarium, które mogą nosić. „Unum igitur orarium oportet levitam gestare in sinistrum humerum propter quod orat, id est praedicat, dexteram autem partem oportet habere liberam, ut expeditus ad ministerium sacerdotale discurrat" $"$.

Interpretacja stuły w kanonie 40. tego synodu ma $\mathrm{z}$ jednej strony charakter etymologiczny, z drugiej zaś symboliczny. W interpretacji etymologicznej „orare” i „praedicare” są ze sobą zrównane. Ta równość nie sprawia wrażenia, jakoby „orare” mogło oznaczać tylko „modlić się”. Trudno też wyjaśnić, co lewe ramię ma wspólnego z zadaniem diakona polegającym na „nauczaniu” (?).

Prawe ramię diakona pozostaje wolne, aby „mógł się poruszać bez przeszkód w swej posłudze przy ołtarzu"74, tzn. diakon powinien móc tak swobodnie, jak to tylko możliwe, posługiwać się prawym ramieniem przy swych czynnościach.

\footnotetext{
71 „Entre les deux, symbole et symbolisé tiennent l'un à l'autre par quelque rapport de rassemblance, d'appartenage, voisinage etc., permettant une de ces substitutions [...] qui mettent en relief la relation qui les justifie": F. Isambert, Rite et efficacité symbolique. Essai d'anthropologie sociologique, Paris 1979, s. I66.

72 Por. S. Wisse, Das religiöse Symbol. Versuch einer Wesensdeutung, Essen 1963, s. 35n.

73 Concilios Visigoticos e Hispano-Romanos, ed. J. Vives, dz. cyt., s. 206.

${ }_{74}$ Tłumaczenie według: J. Braun, Die liturgische Gewandung im Occident und Orient, dz. cyt., s. 570 .
} 
Informacje o tym, jakie to były konkretnie czynności w historycznym kontekście IV Synodu w Toledo, znajdujemy w De ecclesiasticis officiis Izydora z Sewilli († 636), który przewodniczył obradom tego Synodu ${ }^{75}$.

Sine his sacerdos nomen habet, officium non habet. Nam sicut in sacerdote consecratio, ita in ministro dispensatio sacramenti est; ille orare, hic psallere mandatur; ille oblata sanctificat, hic sanctificata dispensat. Ipsis etiam sacerdotibus propter praesumptionem non licet de mensa domini tollere calicem, nisi eis traditus fuerit a diacono. Levitae inferunt oblationes in altario, levitae conponunt mensam domini, levitae operiunt arcam testamenti ${ }^{7}$.

Trudno nie dostrzec, że w opinii Izydora służba diakona była niezbędna. „Bez nich (tzn. diakonów) byłby on kapłanem tylko z nazwy, nie mógłby jednak sprawować swego urzędu" -stwierdził lakonicznie. To stwierdzenie wynika z faktu, że zgodnie z opisaną przez Izydora liturgią kapłan nie mógł sam wziąc kielicha, tylko musiał go przyjąć od diakona. Istotną, spełnianą przez diakona czynnością jest według słów Izydora udzielanie komunii i przygotowanie darów. Ze względu na te czynności powinien mieć on swobodne ręce, w związku z czym jego stuła nie mogła ograniczać prawego ramienia i dlatego powinna spoczywać na lewym ramieniu.

Etymologiczna interpretacja orarium diakona, której podstawą są sformułowane przez IV Synod w Toledo pojęcia „orare” i ,praedicare”, mogłaby się wobec stwierdzeń Izydora opierać na tym, że zadaniem diakona było też recytowanie psalmów (,hic psallere”).

\section{Stuła kaptana}

Centralny punkt odniesienia w historycznym spojrzeniu na stułę kapłana stanowi Rationale Divinorum Officiorum Guillaume'a Duranda (XIII wiek). Sięgnął on do postanowień III Synodu w Bradze (675), które nakazywały „sacerdos" - a więc biskupowi i (lub) kapłanowi - nosić stułę skrzyżowaną na piersi. Uzasadnienie zawarte w dokumencie synodalnym koncentrowało się na konsekwencjach działań i na egzystencji kapłana, który insygniów otrzymanych podczas święceń nie mógł odłożyć podczas wykonywania czynno-

75 Por. J. Braun, Die liturgische Gewandung im Occident und Orient, dz. cyt., s. 569.

${ }^{76}$ Isidor von Sevilla, De ecclesiasticis officiis, s. 67n (Corpus Christianorum. Series Latina, II3). 
ści sakramentalnych ${ }^{77}$. Groźba ekskomuniki, o której wspomina Synod, odnosi się więc do noszenia stuły w ogóle, a nie np. do sposobu jej noszenia, tzn. krzyżowania jej na piersiach.

Mimo to Rationale Duranda zdaje się to właśnie sugerować, nawet gdy jak już stwierdziliśmy - relatywizuje ten nakaz, ponieważ zwyczaj noszenia stuły skrzyżowanej (tylko w ten sposób!) nie wszędzie się przyjąa7 ${ }^{78}$. Zaostrzając napomnienie, Durand sięga po pismo De sacro altaris mysterio papieża Innocentego III. Dopiero tutaj groźba ekskomuniki pojawia się w oderwaniu od napomnienia, by w ogóle nosić stułę79.

Nie narusza to jednak zapisanej tam przez Duranda interpretacji stuły. Nie traci ona wewnętrznej logiki, nawet gdyby stuła nie była skrzyżowana na piersiach.

Sed et secundum decretum Bracharensis concilii debet sacerdos de uno eodemque orario, cervicem pariter et utrumque humerum premens, signum crucis in suo pectore preparare; ut qui imperturbatus precipitur inter prospera et adversa consistere, virtutum semper ornamento utroque circumseptus appareat humero ${ }^{80}$.

Słowami tego samego kanonu III Synodu w Bradze Durand uzasadnia dyscyplinarne zalecenia Synodu. Uzasadnienie, które w dokumencie synodalnym poprzedza zalecenie dyscyplinarne, umieścił on po zaleceniu, aby w ten sposób wskazać wyraźniej na jego uzasadniający charakter. Cytowany przez Duranda dokument synodalny odwołuje się do faktu, iż stuła kapłana spowija go z obu stron, co ma odzwierciedlać sytuację człowieka, który wie, że w dobrych i złych chwilach powinien okazać stałość. Tę zdolność zyskuje dzięki noszeniu stuły. Stuła, która spoczywa na obu jego ramionach, obdarza go cnotą stałości, która jest widoczna w różnych momentach jego życia.

Zarówno III Synod w Bradze, jak i Durand wychodzą od bardzo konkretnej przesłanki, czyli sposobu noszenia przez kapłanów stuły na obu ramionach. Sama interpretacja stuły i sposobu jej noszenia ma jednak raczej

77 Por. Concilios Visigoticos e Hispano-Romanos, ed. J. Vives, dz. cyt., s. 375.

78 Por. G. Durantis, Rationale Divinorum Officiorum I-IV, s. I9I (Corpus Christianorum. Continuatio Medievalis, I40).

79 Por. P. Innozenz III., Il Sacrosancto Mistero dell'Altare (De Sacro altaris mysterio), s. 86nn (Monumenta Studia Instrumenta Liturgica, I5).

80 G. Durantis, Rationale Divinorum Officiorum I-IV, I9I (Corpus Christianorum. Continuatio Medievalis, I40). 
charakter alegoryczny, ponieważ trudno się w niej dopatrzeć odniesienia do święceń i urzędu kapłana. Podobny charakter ma interpretacja Iwona z Chartres, który swobodnie zwisające pasy stuły interpretuje w ten sposób, że kapłan może się bronić „po prawicy i lewicy”, w dobrych i trudnych czasach „bronią sprawiedliwości”8I.

Inaczej interpretuje kapłańską stułę Hraban Maur († 856). W piśmie De institutione clericorum wychodzi w swych rozważaniach na temat orarium kapłana od sposobu jego noszenia wokół szyi i na piersiach oraz etymologii tego pojęcia, odnosząc je do czynności kapłana w jego posłudze głoszenia Słowa Bożego.

Hoc enim genere vestis (i.e. orarium) solummodo eis personis uti est concessum, quibus praedicandi officium est delegatum. Bene etiam oratoribus Christi orarium habere convenit, quia, cum indumentum eorum officio proprio concinnat, et ipsi sedulo ad verbi ministerium cohortantur et plebs ipsis commissa indicium salutare conspiciens ad meditationem legis die concurrere ferventius admonetur. Apte ergo orarium collum simul et pectus tegit sacerdotis, ut inde instruatur, quod quicquid ore proferat, tractatu summae rationis adtendat ${ }^{82}$.

Pojęcie „oratores” odnosi się tu nie do modlących się, lecz do mówców, a więc osób sprawujących posługę Słowa Bożego. Hraban ma przy tym na myśli kapłanów ${ }^{83}$. Ci, którzy w mowie („oratio”) mają interpretować Słowo Boże, noszą orarium.

Noszenie orarium jest dla nich napomnieniem, by swą posługę wykonywali pilnie (,sedulo"), a dla ludu, by dostrzegał ten „zbawczy znak” (,indicium salutare"). Powierzony im lud powinien więc być, jak widać, wzywany poprzez oglądanie stuły (!) do gromadzenia się w celu poznania prawa Bożego. Najprawdopodobniej nie chodzi tu o homilię głoszoną podczas uroczystości eucharystycznej, ponieważ ten zwyczaj zanikł już w Ordines czasów karolińskich $^{84}$. Homilia była jednak zadaniem, którego konieczność często wspomi-

\footnotetext{
81 Por. Ivo von Chartres, Sermones, s. 525 (Patrologia Latina, I62).

82 Hraban, De Institutione Clericorum, dz. cyt., s. I75n.; wtrącenie w nawiasie: Riegel.

83 Por. Hraban, De Institutione Clericorum, dz. cyt., s. I52.

${ }_{84}$ Por. M. Morard, Quand liturgie epousa prédication. Note sur la place de la prédication dans la Liturgie Romaine au Moyen Âge (VIIIe-XVIe siècle), s. 86.
} 
nano na ówczesnych synodach ${ }^{85}$. Nie można więc wykluczyć, że pewien bliżej nieokreślony rodzaj homilii głoszony miał być przez kapłana bez ornatu.

Jest dla Hrabana oczywiste, że podczas tej czynności kapłan nosi orarium, które przykrywa jego szyję i piersi, przypominając mu, że wszystko, co mówi, powinien wcześniej dobrze rozważyć w swym wnętrzu. W piśmie Hrabana nie ma mowy o sercu, można jednak wywnioskować z kontekstu, że chodzi tu o „rozważanie w sercu”, ponieważ miejscem rozumu (,ratio”) jest serce (,pectus”) jako centrum klatki piersiowej. Umiejscowienie rozumu („ratio”) w sercu nie jest dla Hrabana jedyną opcją, nie stanowi też jednak koncepcji zupełnie mu nieznanej ${ }^{86}$. Kapłanowi, któremu zlecono głoszenie homilii, spoczywająca na jego sercu stuła powinna była przypominać, że słowa głoszone przez niego podczas homilii powinny zostać rozważone w sercu i przemyślane, tak by nie wypowiadał ich bez rozwagi. Spełnia on bowiem posługę głoszenia Słowa Bożego.

\section{Współczesna interpretacja liturgiczna - przekazanie szat podczas liturgii święceń}

Odnowione Pontificale Romanum przypisuje ceremonii przekazania szat podczas święceń diakonatu i święceń kapłańskich wyraźnie podrzędne znaczenie. Szaty nakłada się po odmówieniu przez biskupa modlitwy konsekracyjnej, a przekazywane są one nie przez samego biskupa, lecz przez jednego z diakonów lub akolitów (podczas święceń diakonatu) lub też jednego z obecnych kapłanów (podczas święceń kapłańskich) ${ }^{87}$. Z tego względu - ściśle rzecz biorąc - nie są już nawet zaliczane do objaśniających znaków konsekracji ${ }^{88}$. Lameri przypisuje jednak tym obrzędom dzisiejszej liturgii szczególne znaczenie: zamiast jednostronnie akcentować centralny obrzęd nałożenia rąk, konkretyzują one wyproszone dla kandydatów u Boga dary łaski w myśl

\footnotetext{
85 Por. J. Chélini, L'aube du Moyen Âge. Naissance de la chrétienité occidental, Paris I99I, s. $84-\mathrm{IOO}$.

86 Por. W. Gewehr, Zu den Begriffen ,, anima” und ,cor” im frühmittelalterlichen Denken, „Zeitschrift für Religions- und Geistesgeschichte” 27 (1975), s. 54.

87 Por. Pontificale Romanum ex decreto Sacrosancti Oecumenici Concilii Vaticani II..., dz. cyt., s. 94, I39.

88 Por. B. Kleinheyer, Ordinationen und Beauftragungen, w: Gottesdienst der Kirche. Handbuch der Liturgiewissenschaft, ed. B. Kleinheyer, al., T. 8 Sakramentliche Feiern II, Regensburg 1984, s. 5I.
} 
Praenotanda generalia $\mathrm{z}$ tomu De ordinatione episcopi, presbyterorum et diaconorum Pontyfikału Rzymskiego ${ }^{89}$.

Magni momenti intra Ordinationis celebrationem sunt ritus praeparatorii, nempe praesentatio electi vel electio candidatorum, homilia, promissio electorum et supplicatio litanica, et praesertim ritus explicativi, diversi pro diversitate Ordinis, quibus indicantur munera per manuum impositionem et invocationem Spiritus Sancti collata ${ }^{90}$.

Obrzędy objaśniające podczas święceń mają unaocznić kandydatom, jakie dary łaski zostały dla nich w ich święceniach wymodlone. Zaliczamy do nich obrzęd przekazania Ewangelii podczas święceń diakonatu, namaszczenie rąk oraz przekazanie kielicha i pateny z darami eucharystycznymi podczas święceń kapłańskich ${ }^{91}$. Nałożenia insygniów i stroju przewidzianego do święceń nie można zaliczyć do znaków objaśniających choćby dlatego, że nie są dokonywane przez biskupa. Stąd zbędne jest pytanie o to, na jakie dary łaski („munera collata”) wskazuje strój i nakładana przez diakonów i prezbiterów stuła.

Jaką wymowę ma więc moment, w którym nowo wyświęcony diakon otrzymuje stułę i dalmatykę, a nowo wyświęcony kapłan stułę prezbitera i ornat? Interpretację mogą nieco ułatwić przewidziane na okazję obu święceń psalmy, które należy odśpiewać podczas nakładania szat.

Psalm przewidziany na czas nakładania stuły i dalmatyki podczas święceń diakonatu [Psalm 83 (84)], umieszcza czynności konsekracyjne diakonów w szerszym kontekście eklezjologicznym, gdy w tekście jako błogosławieni wymieniani są ci, którzy mieszkają w domu Boga, a w opisie drogi kreślony jest sukcesywnie obraz Kościoła Bożego.

Ant.: Beati qui habitant in domo tua, Domine. T.P. Alleluja. Quam dilecta tabernacula tua, Domine virtutum! * Concupiscit et deficit anima mea in atria

\footnotetext{
89 Por. A. Lameri, La traditio instrumentorum e delle insegne nei riti di ordinazione. Studio storico-liturgico, s. 2I2nn (Bibliotheca Ephemerides Liturg. Subsidia, 96); Lameri ma jednak w kilku punktach watpliwości, czy obrzędy objaśniające w dzisiejszej formie spełniają swoją funkcję.

90 Pontificale Romanum ex decreto Sacrosancti Oecumenici Concilii Vaticani II..., dz. cyt., 2 (Praenotanda, n. 8).

91 Por. Pontificale Romanum ex decreto Sacrosancti Oecumenici Concilii Vaticani II..., dz. cyt., s. 95, I39.
} 
Domini. Cor meum et caro mea * exsultaverunt in Deum vivum. Etenim passer invenit sibi domum, $\uparrow$ et turtur nidum sibi, ubi ponat pullos suos: * altaria tua, Domine virtutum, rex meus, et Deus meus. Beati qui habitant in domo tua: * in perpetuum laudabunt te. Beatus vir cujus est auxilium abs te, * ascensiones in corde suo disposuit. Transeuntes per vallem sitientem, in fontem ponent eam, * etenim benedictionibus vestiet eam pluvia matutina.

Ibunt de virtute in virtutem, * videbitur Deus deorum in Sion. Domine Deus virtutum, exaudi orationem meam; * auribus percipe, Deus Jacob.

Protector noster, aspice, Deus, * et respice in faciem christi tui. Quia melior est dies una in atriis tuis super milia; $\dagger$ elegi ad limen esse in domo Dei mei * magis quam habitare in tabernaculis peccatorum.

Quia sol et scutum est Dominus Deus, $\dagger$ gratiam et gloriam dabit Dominus; * on privabit bonis eos, qui ambulant in innocentia. Domine virtutum, * beatus homo qui sperat in te ${ }^{92}$.

Psalm ten otwiera w kontekście święceń diakonatu szerszą płaszczyznę znaczeniową: od trwania w powołaniu nowo wyświęconego diakona (,beatus vir...”) po obecność Boga we wspólnocie tych, którzy zgromadzili się na mszy świętej dla tych święceń i dla których diakoni przyjęli święcenia („,beati qui habitant...”). Przede wszystkim jednak otwiera się tu wymiar niemalże biograficzny, w którym całe życie diakonów pokazane jest za pomocą pojęć związanych z ruchem (ascensiones, transeuntes, ibunt, ambulant). Na wszystkich tych drogach diakoni i Kościół zyskują przekonanie, że (z Bożą pomocą) nawet suchą dolinę mogą przemienić w źródło (,transeuntes per vallem sitientem, in fontem ponent eam") i że Bóg jest dla nich „słońcem i tarczą” we wszystkich trudnościach (,,sol et scutum est Dominus Deus"). W chwili, gdy diakoni ubierani są w przysługujące im szaty - i stułę - ta perspektywa obejmuje ich własne życie.

Na czas nakładania szat podczas święceń kapłańskich przewidziany jest Psalm IO9 (IIO). Jak zauważa Buchinger, jest on interpretowany chrystolo-

92 Pontificale Romanum ex decreto Sacrosancti Oecumenici Concilii Vaticani II..., dz. cyt., s. I23n. 
gicznie, w rozumieniu „vox Dei”, czyli jako mowa, w czasie której Ojciec przemawia do Chrystusa ${ }^{93}$.

Sacerdos in aeternum * Christus Dominus secundum ordinem Melchisedech, panem et vinum $\dagger$ obtulit. T. P. $\dagger$ obtulit, alleluia. Dixit Dominus Domino meo: * «Sede a dextris meis, donec ponam inimicos tuos * scabellum pedum tuorum». Virgam potentiae tuae emittet Dominus ex Sion: * dominare in medio inimicorum tuorum. Tecum principatus in die virtutis tuae, $\uparrow$ in splendoribus sanctis, ${ }^{*}$ ex utero ante luciferum genui te... ${ }^{94}$.

Już choćby tylko ze względu na nowotestamentową recepcję tego Psalmu (por. Mt 22, 4I-45) z całą pewnością nie można odczytywać go w sposób antropologiczny ani eklezjologiczny. W tym momencie obrzędu święceń umieszczony został jako psalm skoncentrowany na postaci Chrystusa jako Arcykapłana (patrz antyfona „Sacerdos in aeternum...”). Niedopuszczalne byłoby odnoszenie go do osoby nowo wyświęconego kapłana. Jego sens ujawnia się jedynie w horyzoncie działania „in persona Christi capitis"95. Wyświęcany kapłan stoi przed tym niesłychanym wyzwaniem nie tylko w chwili, gdy ubierany jest w kapłańską stułę i ornat, ale też przez całe swoje życie. Perspektywa tej czynności konsekracyjnej obejmuje całe życie nowego kapłana .

Czynności konsekracyjne są dla kandydatów przełomowymi momentami w ich życiu. Fakt, iż w chwili nakładania szat nie stoją przed biskupem, być może jeszcze bardziej uzmysławia im doniosłość tego kroku na tle całego ich życia.

Przy takich okazjach widać, że to, co pozornie uboczne, zyskuje na znaczeniu, gdy dotyka się sfery humanum. Ubiór ma wiele wspólnego z życiem w „przestrzeni własnego ciała”. Ma też wpływ na to, czy uczestnicy będą umieli obronić swą podmiotowość w przypisanej im roli, czy też nie ${ }^{96}$.

${ }_{93}$ Por. H. Buchinger, Zur Hermeneutik liturgischer Psalmenverwendung. Methodologische Überlegungen im Schnittpunkt von Bibelwissenschaft, Patristik und Liturgiewissenschaft, „Heiliger Dienst” 54 (2000), s. 220.

94 Pontificale Romanum ex decreto Sacrosancti Oecumenici Concilii Vaticani II..., dz. cyt., s. 77.

95 Por. Pontificale Romanum ex decreto Sacrosancti Oecumenici Concilii Vaticani II..., dz. cyt., 53; Praenotanda, s. IOI.

96 A. Gerhards, Geschichte-Gegenwart-Perspektiven, dz. cyt., s. 90. 
Stosunkowo nieformalne przekazanie szat umożliwia konieczne właśnie przy tej czynności uwzględnienie humanum w odniesieniu do wyświęcanych diakonów i kapłanów. Ubrana szata i stuła przynależą do przestrzeni własnego ciała, by mogły oznaczać jedynie funkcje związane z ich służbą. Chodzi tu bowiem o całość egzystencji osób konsekrowanych.

\section{Podsumowanie: STUŁA - DUCHOWOŚĆ SYMBOLIZOWANA PRZEZ TKANINE}

Pojęciem, którego na pewno nie należy stosować do stroju liturgicznego, jest kostium. Kto sprawuje posługę liturgiczną, ten nie zakłada przebrania. Szczerość stanowi niezbywalny warunek komunikacji werbalnej, a komunikacja symboliczna w niczym od niej pod tym względem nie odbiega. „Interpretatorzy nie mogą «się maskować» ani pozorować czegoś, czym w rzeczywistości nie są, nie mogą udawać wiary, której nie mają. [...] To oczywiste, że ironia i drwina nie są właściwymi znakami w liturgii" ${ }^{97}$.

Z tej perspektywy strój liturgiczny musi być symbolem i wyrazem wiary tego, kto go nosi. W odniesieniu do stuły oznacza to szczerą postawę wobec przyjmowanych święceń diakonatu lub święceń kapłańskich.

Jak długo fakt przyjęcia święceń, a tym samym pewnej formy życia będzie podstawą symbolicznej interpretacji stuły jako insygnium, interpretacja ta uniknie błędu alegorycznej postsymboliki w kształcie przedsoborowym $^{98}$. Celebrans inspirowany śpiewami liturgicznymi towarzyszącymi przekazaniu szat w dzisiejszej liturgii konsekracyjnej łatwiej może dokonać refleksji nad własną biografią i powołaniem i działać w oparciu o siłę płynącą z sakramentu, który przyjął. Perspektywa historyczna potwierdza przy tym to, co dostrzeżono także w odnowionej liturgii święceń, i co zapisano już w dokumencie z III Synodu w Bradze (675): Jeśli kapłan nie wątpi w znaczenie otrzymania stuły podczas sakramentu święceń, dlaczego miałby go nie używać podczas sprawowania ofiary eucharystycznej?99 Już wtedy stuła była traktowana jako trwały znak odwołujący się do pamięci osoby

\footnotetext{
97 J. Schermann, Die Sprache im Gottesdienst, S. I05 (Innsbrucker Theologische Studien, I8).

98 Por. R. Kaczynski, Über Sinn und Bedeutung liturgischer Gewänder, dz. cyt., s. 94.

99 Por. Concilios Visigoticos e Hispano-Romanos, ed. J. Vives, dz. cyt., s. 375.
} 
konsekrowanej, która powinna go nosić także podczas uroczystości eucharystycznej, by przywoływać to sakramentalne wydarzenie. Trudno znaleźć uzasadnienie, dlaczego dziś miałoby być inaczej.

Tłumaczenie: Katarzyna Jakubów (KUL)

\section{Bibliografia}

Andrieu M. (ed.), Le Pontifical Romain au moyen-âge, t. 3 Le Pontifical de Guillaume Durand, Città del Vaticano 1940 (Studi e Testi, 88).

Andrieu M. (ed.), Ordo XXXIV, w: Les Ordines Romani du haut moyen-âge III. Les Textes (suite), Louvain I95I, s. 603-6r3.

Andrieu M. (ed.), Ordo XXXV, w: Les Ordines Romani du haut moyen-âge IV. Les Textes (suite), Louvain I956, s. 33-46.

Andrieu M., Ordo XXXV. I. Introduction, w: Les Ordines Romani du haut moyen-âge IV. Les Textes (suite), ed. M. Andrieu, Louvain 1956, s. 3-30.

Andrieu M., Ordo XXXVI. I. Introduction, w: Les Ordines Romani du haut moyen-âge VI. Les Textes (suite), ed. M. Andrieu, Louvain 1956, s. II3-I9I.

Arthaber A., Dizionario comparato di proverbi e modi proverbiali italiani, latini, francesi, spagnoli, tedeschi, inglesi e greca antichi, Milano 1986.

Bayer A., Jenisch B., Die Grabgewänder des Abtes Berno von Reichenau († I048). Untersuchungen der Abegg-Stiftung Riggisberg, „Denkmalpflege in Baden-Württemberg" 39 (2013), s. I76-I83.

Berger R., Liturgische Gewänder und Insignien, w: Gottesdienst der Kirche. Handbuch der Liturgiewissenschaft, t. 3 Gestalt des Gottesdienstes, ed. H. B. Meyer i in., Regensburg I9902, s. 309-346.

Boretius A., Krause V. (ed.), Capitularia Regum Francorum t. 2, Hannover I897 (Monumenta Germaniae Historica, Leg. 2, Cap. 2).

Bradshaw P. F., Ordination Rites of the Ancient Churches of East and West, New York 1990.

Braun J., Die liturgische Gewandung im Occident und Orient, Freiburg im Breisgau 1907.

Braun J., Tunic, w: The Catholic Encyclopedia t. I5, ed. C. G. Herbermann i in., New York I9I2, kol. 87n.

Buchinger H., Zur Hermeneutik liturgischer Psalmenverwendung. Methodologische Überlegungen im Schnittpunkt von Bibelwissenschaft, Patristik und Liturgiewissenschaft, „Heiliger Dienst” 54 (2000), s. 193-222. 
40 || Jürgen Riegel SAC

Chélini J., L'aube du Moyen Âge. Naissance de la chrétienité occidental, Paris I99I.

Constitutio de Sacra Liturgia „Sacrosanctum Concilium”, w: Enchiridion Documentorum Instaurationis Liturgicae I, Torino I976, s. I-27.

Duden. Redewendungen. Wörterbuch der deutschen Idiomatik (Duden Band, II), Mannheim-Leipzig-Wien-Zürich 2002.

Durantis G., Rationale Divinorum Officiorum t. I-IV, Turnhout 1995 (Corpus Christianorum. Continuatio Medievalis, I40).

Georges K. E., Ausführliches lateinisch-deutsches Handwörterbuch, Bd. 2, Hannover I9I8.

Gerhards A., Geschichte - Gegenwart - Perspektiven», w: Casula, Katalog zu einer Ausstellung vom 3.6.-I6.8.1992 in der Kunst-Station Sankt Peter Köln, Köln I992, s. 86-95.

Gerhards A., Textilien im Kontext von Kirchenraum und Liturgie. Bestandsaufnahme und Desiderate, „Das Münster” 54 (200I), s. 3IO-3I5.

Gewehr W., Zu den Begriffen ,anima” und ,cor” im frühmittelalterlichen Denken, „Zeitschrift für Religions- und Geistesgeschichte” 27 (I975), S. $40-55$.

Hackspiel-Mikosch E., Die Theorie der Uniform. Zur symbolischen Kommunikation einer männlichen Bekleidungsform am Beginn der Moderne, w: Zweite Haut. Zur Kulturgeschichte der Kleidung, ed. A. Holenstein Bern-Stuttgart-Wien 20I0, s. 65-89.

Hollaardt A., Orarium (orarius), w: Liturgisch Woordenboek 2, ed. L. Brinkhoff,Roermond I968, kol. 205I-2053.

Hollaardt A., Stola, w: Liturgisch Woordenboek 2, ed. L. Brinkhoff, Roermond i968, kol. 2594-2597.

Hrabanus, De institutione clericorum Turnhout 2006 (Fontes Christiani 6I,I). Innozenz III., P., Il Sacrosancto Mistero dell'Altare (De Sacro altaris mysterio), Città del Vaticano 2002 (Monumenta Studia Instrumenta Liturgica, I5).

Institutio Generalis Missalis Romani, w: Missale Romanum ex Decreto Sacrosancti Oecumenici Concilii Vaticani II instauratum auctoritate Pauli PP. VI promulgatum Ioannis Pauli PP. II cura recognitum. Editio typica tertia, Città del Vaticano 2002, s. 19-86.

Isambert F., Rite et efficacité symbolique. Essai d'anthropologie sociologique, Paris I979.

Isidor von Sevilla, De ecclesiasticis officiis, Turnhout 1989 (Corpus Christianorum. Series Latina, II3).

Ivo von Chartres, Sermones, Paris I854 (Patrologia Latina, I62).

Janini J. (ed.), Liber Ordinum Episcopal, Silos I99I (Studia Silensia, I5). 
Kaczynski R., Über Sinn und Bedeutung liturgischer Gewänder, „Das Münster" 32 (1979), 94-96.

Kleinheyer B., Ordinationen und Beauftragungen, w: Gottesdienst der Kirche. Handbuch der Liturgiewissenschaft, T. 8 Sakramentliche Feiern II, ed. B. Kleinheyer et al., Regensburg 1984, s. I2-65.

Kleinheyer B., Studien zur nichtrömisch-westlichen Ordinationsliturgie. Folge 4: Zur Bewertung diverser Gewandüberreichungsriten im Licht ihrer Deuteworte, „Archiv für Liturgiewissenschaft” 33 (199I), s. 217-274.

Kunzler M., ,,Kleider machen Liturgen”. Überlegungen zum liturgischen Gewand, „Heiliger Dienst” 64 (2010), s. I76-I9I.

Kunzler M., Liturge sein. Entwurf einer Ars celebrandi, Paderborn 2007.

Lameri A., La Traditio Instrumentorum e delle insegne nei riti di ordinazione. Studio storico-liturgico (BEL.S 96), Roma 1998.

Leclercq H., Étole, in: Dictionnaire d'archéologie chrétienne et de liturgie, t. 5, Paris 1922, kol. 673-676.

Mansi J. D. (ed.), Concilium Laodicenum, w: Sacrorum conciliorum nova et amplissima Collectio, Firenze I759, s. 563-6I4.

Manzoni A., I promessi sposi, w: Tutte le opere, ed. G. Orioli i in., Roma 1965, s. $247-528$.

Marinoni M., Un'antica testimonianza iconografica sull'uso della stola diaconale in occidente, „Ephemerides Liturgicae” 90 (1976), s. 88-99.

Miller, M. C., Clothing the Clergy. Virtue and Power in Medieval Europe, c. 800-I200, New York 2014.

Morard M., Quand liturgie epousa prédication. Note sur la place de la prédication dans la Liturgie Romaine au Moyen Âge (VIIIe-XVIe siècle), w: Prédication et liturgie au Moyen Âge, ed. N. Bériou, F. Morenzoni, Turnhout 2008, s. 79-I26.

Papas A., Liturgische Gewänder, w: Reallexikon zur byzantinischen Kunst, ed. M. Restle, t. 5, Stuttgart 1995, kol. 74I-775.

Pape W., Handwörterbuch der griechischen Sprache, Braunschweig I9I43.

Piccolo Paci S., Storia delle vesti liturgiche. Forma, immagine e funzione, Milano 2008.

Pochmarski E., Stola, w: H. Kühnel, ed., Bildwörterbuch der Kleidung und Rüstung, Stuttgart 1992, s. 253f.

Pontificale Romanum ex decreto Sacrosancti Oecumenici Concilii Vaticani II renovatum auctoritate Pauli PP. VI editum Ioannis Pauli PP. II cura recognitum. De ordinatione episcopi, presbyterorum et diaconorum, Città del Vaticano 19902. 
42 || Jürgen Riegel SAC

Predel G., Vom Presbyter zum Sacerdos. Historische und theologische Aspekte der Entwicklung der Leitungsverantwortung und Sacerdotalisierung des Presbyterates im spätantiken Gallien, Münster 2005.

Richter A., E. Friedberg (ed.), Corpus Iuris Canonici, t. 2, Graz 1955.

Rossi P., Vesti e insegne liturgiche. Storia, uso e simbolismo nel rito romano, Milano 2003.

Schermann J., Die Sprache im Gottesdienst, Innsbruck 1987 (Innsbrucker Theologische Studien, I8).

Schnabel N. C., Die liturgischen Gewänder und Insignien des Diakons, Presbyters und Bischofs in den Kirchen des byzantinischen Ritus, Würzburg 2008.

Schnitzler T., Von Geschichte und Sinn der liturgischen Gewandung und Färbung, „Das Münster” 32 (I979), s. 97-99.

Sodi A. M., Triacca M. (ed.), Missale Romanum. Editio Princeps (I570), Città del Vaticano 1998 (Monumenta Liturgica Concilii Tridentini, 2).

Sodi A. M., Triacca M. (ed.), Pontificale Romanum. Editio Pronceps (I595I596), Città del Vaticano 997 (Monumenta Liturgica Concilii Tridentini, I).

Sommer C. M., Der soziale Sinn der Mode. Kleidung und Mode aus sozialpsychologischer Sicht, w: Zweite Haut. Zur Kulturgeschichte der Kleidung, ed. A. Holenstein i in., Bern-Stuttgart-Wien 20IO, s. 24I-253.

Superson J., Historia stuły, Kraków 20II.

Thonhauser M., Paramente: Textilien für ein Fest, „Heiliger Dienst” 64 (2010), S. I92-20I.

Concilios Visigoticos e Hispano-Romanos, ed. J. Vives, Barcelona-Madrid I963.

Wagner J., Die geschichtliche Entwicklung der liturgischen Gewandung. Welche Hinweise gibt sie uns für eine zeitgenössische Erneuerung?, „Das Münster” 32 (1979), s. 9I-94.

Wisse S., Das religiöse Symbol. Versuch einer Wesensdeutung, Essen I963. 